\title{
PERAN ORANG TUA DALAM MEMELIHARA KESEHATAN GIGI MULUT DENGAN KARIES GIGI PADA ANAK SEKOLAH DASAR KELAS 1-3 DI DESA WORI KECAMATAN WORI KABUPATEN MINAHASA UTARA
}

\author{
Jeana Lydia Maramis ${ }^{1}$, Ni Made Yuliana ${ }^{2}$ \\ 1,2) Jurusan Keperawatan Gigi Poltekkes Kemenkes Manado. Jl.R.W.Mongisidi Malalayang II \\ Manado \\ Email : jeanalydiamaramis@gmail.com
}

\begin{abstract}
ABSRAK
Karies gigi adalah hasil interaksi bakteri dipermukaan gigi, plak atau biofilm, diet sehingga terjadi demineralisasi jaringan keras gigi dan memerlukan cukup waktu untuk kejadiannya.Orang tua sangat berperan untuk mengarahkan perkembangan anak dengan baik dan optimal. Penelitian ini bertujuan untuk mengetahui peran orang tua dalam memelihara kesehatan gigi dan mulut dengan kejadian karies gigi pada siswa kelas 1-3 di Desa Wori Kecamatan Wori.

Penelitian ini bersifat analitik dengan metode cross sectional study. Populasi dalam penelitian ini berjumlah 145 siswa. teknik pengambilan sampel yaitu simple random sampling yang berjumlah 60 orang tua dan siswa. Instrumen penelitian yang digunakan yaitu kuesioner tentang peran orang tua dan lembar pemeriksaan DMF-T pada siswa. Analisa data menggunakan uji chisquare.

Hasil analisis dengan chi-square tentang hubungan peran orang tua dengan indeks DMF-T tidak memenuhi syarat karena terdapat nilai expected kurang dari 5 yaitu 2 cell $(75 \%)$, maka menggunakan uji Fisher's Exact Test diperoleh nilai ( $\mathrm{p}=0,021<\alpha=5 \%$ ) pada tingkat kemaknaan 95\%. maka $\mathrm{H}_{0}$ ditolak dan $\mathrm{H}_{1}$ diterima. Disimpulkan bahwa terdapat hubungan peran orang tua dalam memelihara kesehatan gigi dan mulut dengan karies gigi pada anak Sekolah Dasar kelas 1-3 di Desa Wori Kecamatan Wori Kabupaten Minahasa Utara.
\end{abstract}

\section{Kata kunci : Peran orang tua, DMF-T siswa}

\begin{abstract}
Dental caries is the result of bacterial interactions on the surface of the teeth, plaque or biofilms, dieting so that demineralization occurs in the hard tissue of the teeth and requires sufficient time for their occurrence. Old people are very instrumental in directing the child's development well and optimally. This study aims to determine the role of parents in maintaining oral health with dental caries in students in grades 1-3 in Wori Village, Wori District.

This research is analytic with cross sectional method. The population in this study amounted to 145 students. The sampling technique is simple random sampling, amounting to 60 parents and students. The research instrument used was a parental role questionnaire and a DMF$\mathrm{T}$ examination sheet on students. The analysis test technique used is the chi-square test.

The results of the chi-square analysis of the $2 \mathrm{X} 2$ relationship between the role of parents and the DMF-T index do not meet the requirements because there is an expected value of less than 5, namely 2 cells (75\%), then using the Fisher's Exact Test obtained value $(p=0.021<\alpha=5$
\end{abstract}


$\%)$ at the $95 \%$ significance level. then $\mathrm{H} 0$ is rejected and $\mathrm{H} 1$ is accepted. It was concluded that there was a relationship between the role of parents in maintaining oral health with dental caries in primary school children grades 1-3 in Wori Village, Wori District, North Minahasa Regency.

\section{Keywords: Role of parents, students' DMF-T}

\section{PENDAHULUAN}

Kesehatan gigi dan mulut penting bagi kesehatan dan kesejahteraan tubuh secara umum dimana, mulut merupakan pintu masuknya makanan dan minuman yang masuk ke dalam tubuh. Apabila kesehatan gigi dan mulut terganggu, maka akan berpengaruh pada organ tubuh yang lain. Seperti akan mengganggu proses pencernaan makanan, komunikasi dalam berbicara juga akan tergganggu sehingga kurang percaya diri. ${ }^{1}$

Karies gigi sampai saat ini masih menjadi prioritas masalah karena dapat terjadi pada setiap orang tanpa memandang umur, bangsa maupun keadaan ekonomi. Karies gigi merupakan suatu penyakit yang ditandai dengan kerusakan jaringan yang dimulai dari permukaan gigi (ceruk, fisura, interproksimal), bisa terdapat pada satu permukaan atau lebih dan dapat meluas hingga bagian yang lebih dalam misalnya dari email ke arah pulpa. ${ }^{2}$

Anak usia sekolah merupakan salah satu kelompok yang rentan terhadap karies, karena umumnya masih mempunyai pengetahuan dan perilaku yang kurang terhadap karies gigi. Dalam menjaga kesehatan gigi dan mulut anak, peran orang tua sangat dibutuhkan dimana anak usia sekolah dasar masih membutuhkan bimbingan orang tua. Orang tua mempunyai peran yang penting dalam menjaga kesehatan anak kususnya kesehatan gigi dan mulut dimana, apa yang dilakukan orang tua akan ditiru oleh anaknya. Kebiasaan orang tua menyikat gigi pada saat habis makan dan sebelum tidur akan berdampak positif bagi perilaku anak tersebut. Orang tua juga harus membiasakan anak untuk mengurangi makanan melekat seperti permen, coklat untuk menjaga agar tidak mengalami gigi berlubang karena, proses gigi berlubang dimulai dari bakteri yang berada dalam mulut bercampur dengan sisa makanan akan menghasilkan asam. Asam ini dapat melarutkan permukaan gigi yang disebut dengan demineralisasi, sehingga dalam kurun waktu tertentu jika dibiarkan terus akan menjadi gigi berlubang. Anak yang mengalami resiko karies tinggi akan membutuhkan perawatan yang ekstra dari orang tua. Hal ini dapat berarti kesehatan anak adalah tanggung jawab orang tua. ${ }^{1}$

Peranan adalah perilaku yang dilakukan oleh seseorang terkait oleh kedudukannya dalam struktur sosial atau kelompok sosial di masyarakat, artinya setiap orang memiliki peranan masing-masing sesuai dengan kedudukan yang ia miliki. ${ }^{3}$ Orang tua sangat berpengaruh dalam memberikan pendidikan dan pengajaran pada anak untuk menjadikan generasi muda berkedudukan. Seorang anak mendapatkan pelajaran dalam kehidupan ini untuk pertama kalinya baik dalam segi komunikasi dan tindakan adalah dari orang tua dimana anak- anak mulai menerima berbagai pelajaran dan kepandaian yang diajarkan dan dilatih oleh orang tuanya. Perlahan-lahan pelajaran yang diberikanpun mulai bervariasi, bukan hanya bagaimana menggunakan panca inderanya saja, tetapi mulai membentuk kepribadian sang anak. Bagaimana membuat kepribadian anak 
menjadi anak yang sabar, anak yang tekun, anak yang rajin, anak yang baik hati. Anakanak belajar dari apa yang mereka lihat di dalam rumah dari orang tua dalam mengasuh dan mendidik sang anak, sekolah bukan satu satunya tempat pembelajaran, diluar sekolah anak-anak mendapatkan banyak pengetahuan yang sebagian besar didapat dari orang tuanya. Perkembangan emosi positif sangat penting dalam perkembangan jiwa anak dan perkembangan itu sangat dipengaruhi oleh peran orang tua. Orang tua sangat berperan untuk mengarahkan perkembangan anak dengan baik dan optimal. Demikian juga dalam memelihara kesehatan gigi dan mulut anak, peranan orang tua sangat penting terjaganya kesehatan gigi dan mulut bagi anak. $^{4}$

Pengukuran karies gigi menggunakan indeks. Indeks karies gigi yaitu angka yang menyatakan suatu keadaan klinis. Nilai yang ditetapkan oleh WHO tentang DMF-T yaitu jika karies $\leq 3$ baik dan jika karies $\geq 3$ adalah buruk. Indeks DMF-T adalah angka yang menyatakan suatu keadaan gigi tetap/permanen pada anak yang mengalami kerusakan, hilang ataupun perbaikan yang disebabkan oleh karies. Pengertian dari masing-masing komponen dari DMF-T yaitu sebagai berikut:

D : Decay, yaitu jumlah gigi karies yang masih dapat ditambal

M : Missing, yaitu jumlah gigi tetap yang telah/ harus dicabut karena karies

$\mathrm{F}$ : Filling, yaitu jumlah gigi yang telah ditambal. ${ }^{5}$

Menurut Sriyono (2005), yang harus diperhatikan waktu pemeriksaan memakai indeks DMF-T yaitu:

a. Apabila ada gigi yang ditambal sementara, maka gigi tersebut dimasukkan kriteria D.

b. Apabila sebuah gigi mempunyai 1 atau lebih tambalan pada permukaanya, sedangkan permukaan lain karies, maka gigi tersebut dimasukkan kriteria D.

c. Apabila ada gigi yang telah ditambal dan timbul karies sekunder disekelilingnya, maka gigi tersebut dimasukkan kriteria D.

d. Apabila ada tambalan preventif misalnya fisur silen, maka gigi tersebut tidak dimasukkan kriteria F.

e. Apabila ada tambalan crown karena karies, maka gigi tersebut tidak dimasukkan kriteria F. ${ }^{6}$

\section{METODE}

Jenis penelitian yang digunakan adalah penelitian survei analitik yaitu mencari hubungan variabel bebas dengan variabel terikat. Yang menjadi sampel dalam penelitian ini yaitu orang tua dari siswa SD GMIM Wori dan SD Katolik Wori kelas 1-3 bersama siswanya di Desa Wori Kecamatan Wori, yang berjumlah 60 siswa dan orang tua, dengan menggunakan teknik simple random sampling. Waktu penelitian dilaksanakan pada bulan Juni minggu ketiga dan keempat tahun 2018. Analisa data dalam penelitian ini menggunakan uji statistik $C h i$ Square.

\section{HASIL}

1. Distribusi Peran orang tua siswa dapat dilihat pada Tabel 1 di bawah ini :

Tabel 1. Distribusi Berdasarkan Responden Peran Orang Tua Siswa

\begin{tabular}{ccc}
\hline Peran Orang Tua & Jumlah & $(\%)$ \\
\hline Kurang Baik & 7 & 12 \\
Baik & 53 & 88 \\
\hline Total & 60 & 100
\end{tabular}

Berdasarkan uraian pada Tabel 1 di atas menunjukkan bahwa distribusi peran orang 
tua paling tinggi yaitu pada kategori baik sebanyak $88 \%$ dan kategori kurang baik hanya $12 \%$.

2. Tabulasi silang antara peran orang tua dengan DMF-T pada anak sekolah dapat dilihat pada Tabel 2 berikut ini:

Tabel 2. Hasil Tabulasi Silang Peran Orang Tua Dengan DMF-T

\begin{tabular}{lccccc}
\hline & \multicolumn{4}{c}{ DMF-T } & \multirow{2}{*}{ Total } \\
\cline { 2 - 4 } $\begin{array}{l}\text { Peran Orang } \\
\text { Tua }\end{array}$ & $\begin{array}{c}\text { Kurang } \\
\text { Baik }\end{array}$ & \multicolumn{2}{c}{ Baik } & \\
\cline { 2 - 5 } & $\mathrm{N}$ & $\%$ & $\mathrm{n}$ & $\%$ & $\%$ \\
\hline Kurang Baik & 5 & 2,2 & 1 & 3,8 & 6,0 \\
Baik & 17 & 19,8 & 37 & 34,2 & 54,0 \\
\hline Total & 22 & 22,0 & 38 & 38,0 & 60,0 \\
\hline
\end{tabular}

Berdasarkan uraian pada Tabel 2 diperoleh hasil bahwa peran orang tua dengan kategori baik menghasilkan DMF-T kategori kurang baik berjumlah 19,8\% dan kategori baik berjumlah $34,2 \%$, sedangkan peran orang tua dengan kategori kurang baik menghasilkan DMF-T kategori kurang baik berjumlah 2,2 \% dan kategori baik hanya $3,8 \%$.

3. Hasil analisis uji statistik dengan $C h i$ Square dapat dilihat pada Tabel 3 di bawah ini:

\begin{tabular}{lcc}
\multicolumn{2}{c}{ Tabel 3. Hasil Analisis Uji Chi Square } \\
\hline Variabel & $\begin{array}{c}\alpha \\
\text { (alpha) }\end{array}$ & $\begin{array}{c}\text { Fisher's Exact } \\
\text { Test }\end{array}$ \\
\hline $\begin{array}{l}\text { Peran orang tua } \\
\text { DMFT }\end{array}$ & 0,05 & 0,021 \\
\hline
\end{tabular}

Berdasarkan analisa statistik dengan menggunakan uji Chi Square tabel 2x2 tidak memenuhi syarat karena terdapat nilai ekspektasi yang kurang dari 5, oleh karena itu, uji alternatifnya yaitu uji Fisher's Exact Test pada tingkat kemaknaan $95 \%$ dengan $\alpha$
$=0,05$ dapat didapat nilai $\rho=0,021$, maka dapat disimpulkan bahwa terdapat hubungan antara peran orang tua dalam memelihara kesehatan gigi dan mulut anak dengan karies gigi anak Sekolah Dasar Kelas 1-3 di Desa Wori Kecamatan Wori Kabupaten Minahasa Utara.

\section{PEMBAHASAN}

Peran orang tua dalam memelihara kesehatan gigi dan mulut sangatlah penting untuk menciptakan kesehatan gigi dan mulut yang optimal. Kesadaran akan pentingnya kesehatan gigi dan mulut dimulai dari pengetahuan yang benar tentang cara memelihara kesehatan gigi dan mulut dan diikuti oleh tindakan yang mampu diimplementasikan secara berkesinambungan sehingga memelihara kesehatan gigi itu merupakan obat pencegah terjadinya masalah kesehatan gigi dan mulut yang paling tepat. $^{7}$

Pengetahuan orang tua berperan penting dalam tercapainya perilaku anak untuk mencegah karies gigi. Secara umum tindakan yang didasari oleh pengetahuan dan perilaku orang tua yang baik dalam menuntun anak memelihara kesehatan gigi dan mulut akan berpengaruh pada rendahnya pertumbuhan penyakit gigi berlubang. ${ }^{8}$

Berdasarkan hasil penelitian tentang peran orang tua dengan DMF-T diperoleh, maka diperoleh peran orang tua dengan kriteria baik paling tinggi, yaitu sebanyak $34,2 \%$. Hal ini menunjukkan bahwa, jika peran orang tua baik maka akan menghasilkan kesehatan gigi yang baik pula bagi anaknya, dan sebaliknya jika orang tua hanya tahu tentang kesehatan gigi dan mulut tetapi tidak mengaplikasikannya maka akan berdampak buruk juga bagi kesehatan gigi dan mulut anaknya.

Kurangnya dukungan atau motivasi dari dalam, baik di lingkungan keluarga, 
masyarakat sekitar ataupun kurangnya ketersediaan sarana dan prasarana dapat menjadi hambatan seseorang dalam memelihara kesehatan gigi dan mulutnya. Maka dibutuhkan tindakan positif yang terbuka dan konsekuen dari orang tua misalnya orang tua bersama-sama dengan anaknya sesudah makan melakukan sikat gigi bersama sebelum tidur malam setiap hari. $^{7}$

Hasil analisa dengan uji Chi Square tentang peran orang tua dengan indeks DMFT, maka diperoleh nilai $\rho=0,021<\alpha=$ 0,05 pada tingkat kemaknaan $95 \%$ yang artinya $\mathrm{H}_{0}$ ditolak dan $\mathrm{H}_{1}$ diterima. Hal ini dapat disimpulkan bahwa, adanya hubungan yang signifikan antara peran orang tua dalam memelihara kesehatan gigi dan mulut dengan karies gigi pada anak sekolah dasar kelas 1-3 di Desa Wori Kecamatan Wori Kabupaten Minahasa Utara.

Hasil ini sejalan dengan penelitian yang dilakukan oleh Prasasti (2016), tentang Hubungan Peran Orang Tua Dalam Kebersihan Gigi dan Mulut dengan Kejadian Karies Gigi pada Anak Prasekolah di Taman Kanak-Kanak (TK) PGRI Kelurahan Ngesrep Semarang, yang menyatakan bahwa terdapat hubungan antara peran orang tua dengan karies gigi. ${ }^{9}$

\section{KESIMPULAN}

1. Peran orang tua dengan kategori DMF-T baik akan menghasilkan nilai DMF-T yang baik pula, sebaliknya peran orang tua dengan kategori DMF-T kurang baik akan menghasilkan nilai DMF-T kurang baik juga.

2. Adanya hubungan yang signifikan antara peran orang tua dalam memelihara kesehatan gigi dan mulut dengan karies gigi pada anak Sekolah Dasar kelas 1-3 di Desa Wori Kecamatan Wori Kabupaten Minahasa Utara.

\section{SARAN}

1. Bagi orang tua siswa, agar dapat memperhatikan kesehatan gigi dan mulut anaknya, terlebih dalam menuntun anak menyikat gigi minimal $2 \times$ sehari yaitu pagi sesudah makan dan malam sebelum tidur, mengurangi makan makanan yang manis dan mudah melekat, serta periksakan kesehatan gigi anak di poli gigi yang ada di Puskesmas atau poli klinik gigi lainnya.

2. Bagi pihak sekolah, agar dapat bekerja sama dengan pihak Puskesmas untuk memberikan pendidikan kesehatan gigi dan mulut melalui kegiatan UKGS agar dapat dicegah terjadinya gigi berlubang.

3. Bagi peneliti selanjutnya, perlu dilakukan penelitian dengan variabel lain agar dapat membantu orang tua dalam memaksimalkan peran mereka untuk memotivasi anak dalam memelihara kesehatan gigi dan mulut.

\section{DAFTAR PUSTAKA}

1. Sariningsih, E. (2014). Gigi Busuk dan Poket Periodontal Sebagai Fokus Infeksi.

PT Elex Media Komputindo. Jakarta.

2. Tarigan, R. (2013). Karies gigi. EGC. Jakarta.

3. Suharso., Retnoningsih Ana., dan Gunawan. (2014). Kamus Besar Bahasa Indonesia. Widya Karya. Semarang.

4. Graha, C. (2007). Keberhasilan Anak di Tangan Orang Tua. PT Elex Media Komputindo. Jakarta.

5. Herijulianti, E., Tati, S.I., dan Sri, A., (2001). Pendidikan Kesehaan Gigi. EGC. Jakarta.

6. Sriyono. (2005). Pengantar Ilmu Kedokteran Gigi Pencegahan. 
MEDIKA-Fakultas Kedokteran UGM. Yogyakarta.

7. Hidayat, R. dan Tandiari,A. (2016). Kesehatan Gigi dan Mulut. Andi Offset. Yogyakarta

8. Budiharto. (2009). Pengantar Ilmu Perilaku Kesehatan dan Pendidikan Kesehatan Gigi. EGC. Jakarta.

9. Prasasti, I. (2016). Hubungan Peran Orang Tua Dalam Kebersihan Gigi Dan Mulut Dengan Kejadian Karies Gigi Pada Anak Prasekolah Di Taman
Kanak-Kanak (TK) PGRI Kelurahan Ngesrep Semarang. Artikel.

Emprits.undip.ac.id. 